\title{
THE EFFECT OF CYCLOSERINE IN MURINE LFPROSY
}

\author{
Shinji NISHIMURA and Kenji KOSAKA \\ (Research Institute for Microbial Diseases of Osaka University) \\ Tadao YASUKAWA \\ (Department of Dermatology, Medical School of Osaka University)
}

Cycloserine was administered in a dose of $1.0 \mathrm{mg}$ daily, 6 days a week for 120 days in mice inoculated with a small quantity or large quantity of murine leprosy bacilli and the effect compared to that in the untreated control.

No effect was noted in the groups inoculated with either the small or large quantity of bacteria and no difference due to the dose of cycloserine was found. In other words, there was no difference between the treated group and the untreated control. From the results, it is believed that this agent has no effect in murine leprosy.

The results differ from those of Chang, but this may be attributed to the difference in experimental methods. A universal standard screening method should be set up as soon as possible.

\section{Cycloserine の鼠癩発症抑制効果}

\author{
西 村 真二・高 坂 健 二

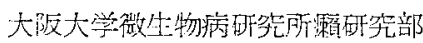 \\ 安师忠雄
}

(1958年 12 月 2 日 受稿)

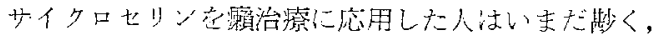

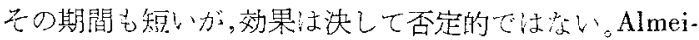

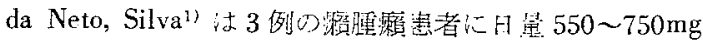

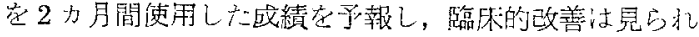

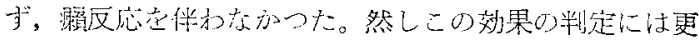

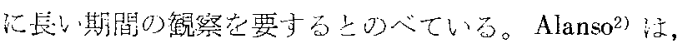

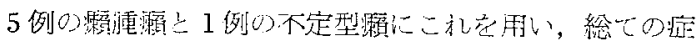

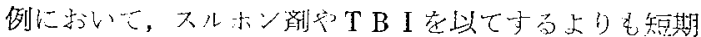

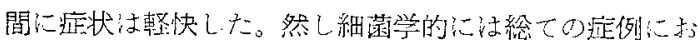
いて依然として陽性ですたと報告し，又 Bertaccini3)

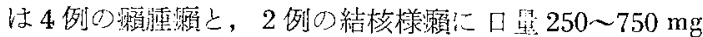
投与， $2 \sim 6$ 力月後の絬果已して，1例の瘦腫嬾と，1

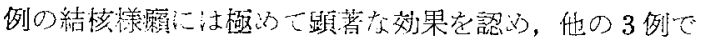

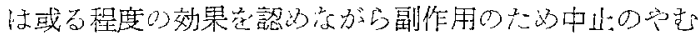

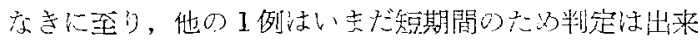
机い上発表してい方。

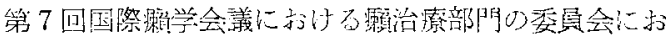
いては本斉について次の上うに結䜊した，即も，諸家の

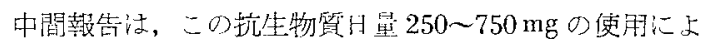

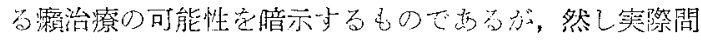

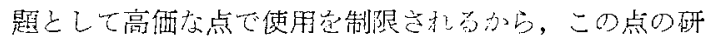
乫が先決問題でふうと。

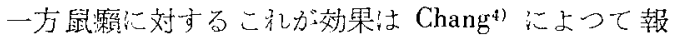

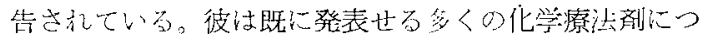

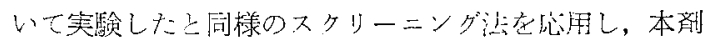

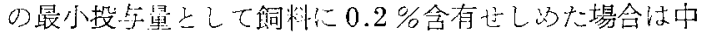


等度の效果定示し，更に大量 0.5 1.0\%含有せしめた 場合にはほほ泳ストレプトマイシンと同一程度の効果を認

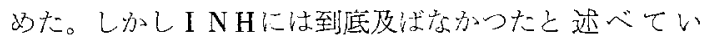
る。

わ叔打机は1958华 2 月塩野義製薬より本剤の提供学受

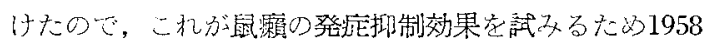
年: 3 月より 8 月に亘つて実験を行つたのでここにその所 見巷報告与る。

\section{実 験 方 法}

動物： $\mathrm{ddO}$ 等ヤウス $ᄋ ， 15 \mathrm{~g} \pm 1 \mathrm{~g}$ 。

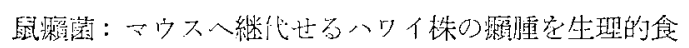

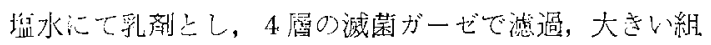

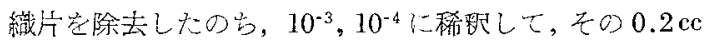
を西村一层佐のスタリーニング法汇良つて下腹部一皮下 注射した。接種時の藕数注 $10^{-3}$ 液 $0.2 \mathrm{cc}=270$ 万個, $10^{-4}$ 液 $0.2 \mathrm{cc}=24$ 万㑑であつた。

サイクロセリンの投与：

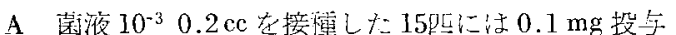

B 同上 15行 $1.0 \mathrm{mg}$ ”

C 菌液 $10^{-4} 0.2 \mathrm{cc}$ 空接種した 15 辰に $0.1 \mathrm{mg}$ ”

D 同上 15以G $1.0 \mathrm{mg} "$ 刘悠群

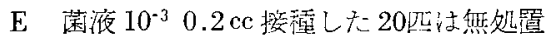

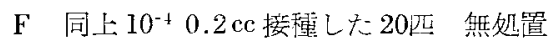

このように按種藏星に1：1/10の差をつけたものと,

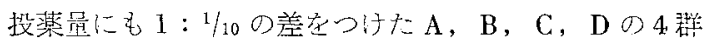

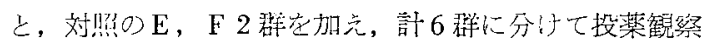

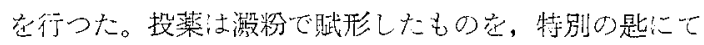
直接経口投与し，120日に亘り1週6月1日休㩰の方法 崖子つた。

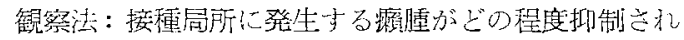

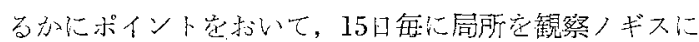

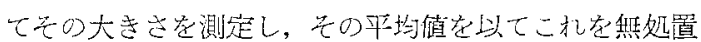
対品椎の平均值と比䡆した。

测定の方法並に指数えの换算はずでて西村一岩作》の 標潐に従つた。

\section{実 験 成 績}

鼠濑菌 $10^{-3} 0.2 \mathrm{cc}$ 穴接稿したマウス：この組では， 然処置の場合, 接棰後 30 60口の間に指数が略々 2.0 程

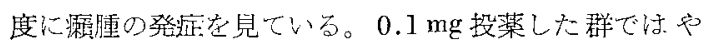

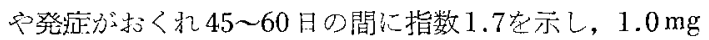
投薬群では無处置群之䀩々同㥞の発淀它兒た。そして各

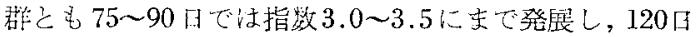
では無处䈯群 $3.8,0.1 \mathrm{mg}$ 投与群, $3.4,1,0 \mathrm{mg}$ 投与群

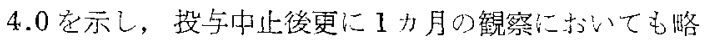
同様の状態でらなた。

鼠楅菌 $10^{-4} 0.2 \mathrm{cc}$ 安接種したマウス：この組では無 奶置の群が 30〜60日の間に指数 $0.1 \sim 1.0$ 实でに発症し た。これに対し，0.1 mg 突投与した群では40〜60月で 0.3 を示し, $1.0 \mathrm{mg}$ 投与群では $45 \sim 60$ 日茕 0.6 であつ

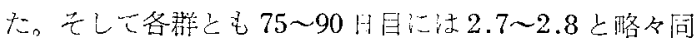

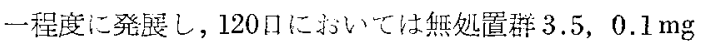
投与 $3.3,1.0 \mathrm{mg}$ 投守 3.4 崖示し，投菜中止後 1 力月の 䚁祭で何れも指数 4.0 选上江及えだ。

The Effect of Cycloserine in Murine Leprosy

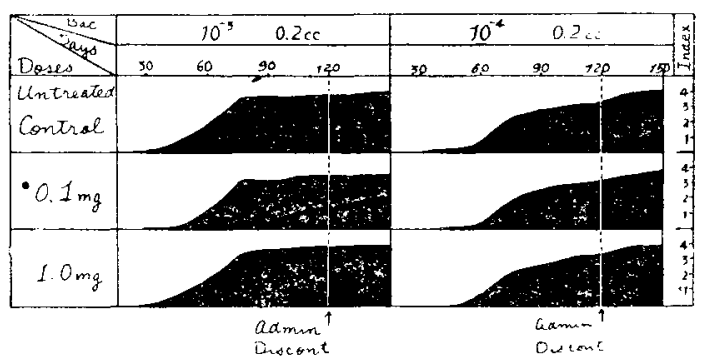

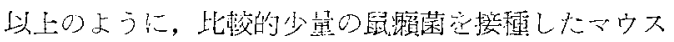

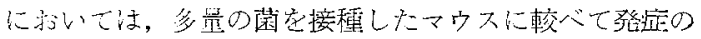

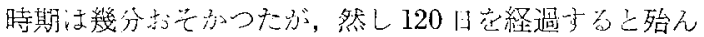

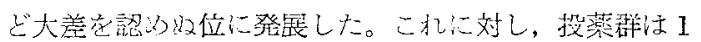

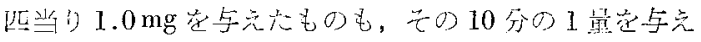

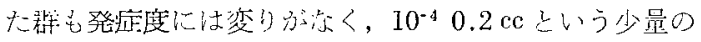
菌定接種した郡に対しても120日間投与て殆儿ど影響な

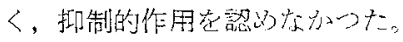

\section{総括並に考案}

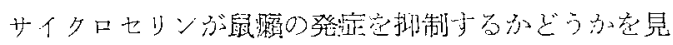

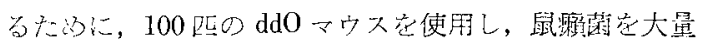

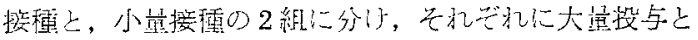

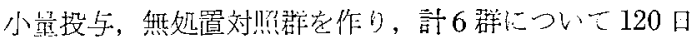
間投薬し，西村一岩佐のスクリーニング沙を応用して成

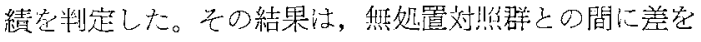
認好ず，本詴に鼠顆発症揤制作用のないことが明吩にな 孛。

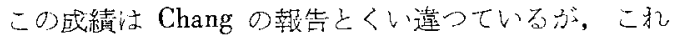

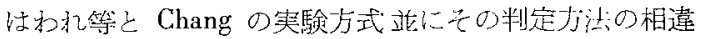
から来たものであるう。同一薬剂に㧈けるかようなデー タの相違は，単にサイクロセりンの場合の子ならず，他

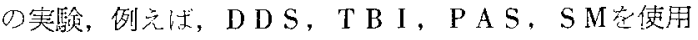


した諸家の間にも見られるので，さきに西村的法，スタ リーニング法の国際的基準協定の必要学提晿したので方 るが，今回の実験心よつて一層との感を深くした次第で ある。

\section{文献}

1) Almeida Neto, E., D. P. Silva : Resultados preliminares do emprês da D-4 amino-3 Isoxazolidinone no tratamento de três casos lepromatosos. Revista Brasileira Leprologia 25, 127-130 (1958)

2) Alanso, A. M. : Cycloserine in Leprosy Therapy. VII International Congress of Leprology, Abstracts of Papers 149 (1958)

3) Bertaccini, G.: Cycloserine in the Treatment of
Leprosy (Preliminary Report) VII International Congress of Leprology, Abstracts of Papers 155 (1958)

4) Chang, Y. T.: Chemotherapy of Murine Leprosy. VII the Effect of Cycloserine on Mouse Leprosy. Internat. J. Leprosy, 25, 257-264 (1957)

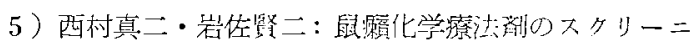

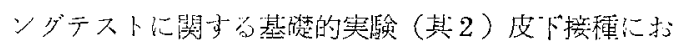

ける龙績判定法の簡易化とマウスの系統挥执について レプラ 24, 405-4.15 (1955)

6) Nishimura, S.: Screening Test of Chemotherapeutics for Leprosy Using Murine Leprosy. VII International Congress of Leprology, Abstracts of Papers 182 (1958) 